\title{
Chapter 7 \\ Researching National and International Top Managers: An Interview with Michael Hartmann
}

\author{
Mikael Palme
}

What were the main reasons behind deciding to carry out research on elites?

There were three main factors influencing the direction that my research took. The first one can be found in my family origin; the second is related to my political orientation that was formed during the time of the leftist student movement in Germany in the 60s and 70s; and the last one is what you can call chance, circumstances that very well could have turned out differently from what they did.

Starting with chance, my early career went very fast. At the age of 30, I got my habilitation, the dozentur; at 32, I had my first university position as a guest professor. You can be fortunate, even if you have no bonds to an academic network that protects you and even if you, being a leftist as myself, are an outsider. However, my luck ended. So, I suddenly found myself unemployed for almost one year, without having any plan B. Then the employment office suddenly offered me a position at the Law Faculty in Bochum, which I accepted. I had two small children to take care of and made a deal with the faculty: since I lived 130 kilometres from Bochum, I could work from home two or three days a week on two conditions. I had to lecture about the sociology of law, and I had to raise research funding by the German Research Foundation (DFG).

At that time, two big databases had newly been created comprising court cases, Juris and Solis. There was an interest in knowing to what extent they were actually consulted by lawyers in their practice. I made a research project funded by the DFG that showed that no lawyers outside the insurance branch ever used them. I did interviews, about 100 , all in very big corporations. I had to do a sample, so in the major branches of the German economy, I selected two of the three leading companies; for example, BMW in the auto industry, Bayer in the chemical industry, the

\footnotetext{
M. Palme $(\square)$

Sociology of Education and Culture (SEC), Uppsala University, Uppsala, Sweden

e-mail: mikael.palme@edu.uu.se
} 
Deutsche Bank in the financial sector and the Allianz in the insurance industry. In each sector, I wanted the leading companies.

Coming myself from a bourgeois family, I recognised these people. My father had a high position as a financial director in a large Catholic institution with a yearly economic overturn equal to that of rather big corporations. He was one of its four top decision makers with the cardinal at the top. I was familiar with how they spoke, dressed and acted. This became clear to me when the project was already underway. It was not planned to address such issues, so I had to return to many of the interviewees afterwards to ask for information on their origin. And it was true: nearly all of them were children of the bourgeoisie. ${ }^{1}$

I belong to the 1968 generation. Already in secondary school, we revolted against our school principal who was a reactionary, authoritarian deputy mayor for the CDU party. For years, he tried in vain to get me expelled for my leftist orientation.

\section{How did you proceed?}

I was not at this moment sufficiently established for getting further funding for my research from the German Research Foundation. I decided to compare the recruitment and careers of computer scientists in large corporations to that of lawyers. Computer scientists belonged to a new profession established in the 70s. On the contrary, lawyers have historically always been close to power. For both professions, social origin turned out to be important. While lawyers, in their majority, traditionally came from the upper or upper middle class, computer scientists often had their origins in the middle classes and, to some extent, also the working classes. Part of my research interest was to study top managers. Among the computer scientists, those who reached management positions had the same bourgeois origin, and they were all male. ${ }^{2}$

\section{In 1996, your book on top managers in German corporation appears. ${ }^{3} \mathrm{How}$ did you get access to people in such high positions?}

I continued to target managers, but only members of the boards of large German corporations. I applied various criteria for selection in order to cover the main branches in the German economy. I used my growing network of contacts, and I also added a new group: the leading head hunters. My belief was that they would reveal mechanisms that operate in the selection and recruitment to elite positions.

At this time, I could still make interviews with top managers without them connecting me to any particular position. Later, I couldn't. I became well-known because of the media. But, at this time, I could make use of my personal network of contacts. I knew who was the head of particular sections in the leading corporations.

\footnotetext{
${ }^{1}$ The results of this research were published in Michael Hartnmann, Juristen in der WirtschaftEine Elite im Wandel, 1990.

${ }^{2}$ Michael Hartmann, Informatiker in der Wirtschaft, 1995.

${ }^{3}$ Michael Hartmann, Topmanager - Die Rekrutierung einer Elite, Frankfurt a. M.: Campus 1996.
} 
I also knew how to find ways to get in contact with them, even when access was denied through normal channels. For example, if I had called the secretary many times only to get the answer that the board director was busy or not present, I had learned that secretaries go home from work sometimes after 5 p.m., so if I called at half past 5, with a bit of luck, the director would answer the phone personally. It is much more difficult to say no when you speak to someone directly. When I could, I made use of contacts since members of the elite much more easily open doors. For the head hunters, for example, I knew that one of them was regarded as the most experienced and effective one in the whole country, so I called him and said that I was well-aware that he normally gave no interviews, but that all his colleagues said that he was the best one and that I simply had to interview him to get things right. He was flattered, and then he helped me.

\section{Did you have an interview guide and how did you handle all the data you collected?}

I had a very extensive interview guide. During the course of field work, you discover new angles and topics, but with so many interviews, you come to a point where you need to keep to the structure of the interview guide so that information is not missing for some of the interviewees. Many questions were very precise. I also collected as much information as I could from other sources on the interviewed top managers. Moreover, I read existing studies on the various corporations and professions the top managers came from. Again, data needed to be systematically collected for the whole population. I like mathematics, so it is not accidental that my studies comprise much exact data. However, my analysis also puts forward qualitative aspects. As you can see in my publications, this is the time when I start making reference to Bourdieu's 'habitus' concept. The head hunters' stories reveal the importance of origin connected to manners, language, educational diplomas and general knowledge. Note that this was not a small sample of merely qualitative interviews, but a fairly representative population of elite positions in major corporations.

\section{To what existing research traditions did you relate?}

I think I am very much an outsider. In fact, I have never belonged to any particular school or research network. When I started, research on elites was dormant in Germany. Since the early 1960s and the work of Dahrendorf and Zapf, only political scientists were focussing on the importance of networks, inspired by Inglehart's idea of the shift from materialistic to post-materialistic values. It had virtually no impact on sociological research. My own position was totally different, in two respects. I opposed the functionalist perspective and instead put power in the foreground. Moreover, I focussed empirically on the recruitment to various elite positions and how it is connected to class structures. From my early times as a student, I was well familiar with both Marx's and Weber's theories of class. The next inspiration came from Bourdieu, whom I learned to know through his first German translator Beate Krais. She introduced me to several articles in Actes de la recherche en sciences sociales and, later, to The State Nobility (Bourdieu 1996). I have never seen myself as a theoretician of elites. My position has rather been that I have to be 
familiar with all contributions, theoretical and empirical, to the sociology of elites, and then I empirically address issues that I find challenging. Take the German sociological heritage as regards elite research at the time when I started my research: I never liked Dahrendorfs' functionalism. Nevertheless, I found his discussion interesting about the reasons for the selective character of recruitment to the dominating class. I wanted to analyse what importance social origin had - independently of the education system - for attaining elite positions.

I stand close to my Marxist origin. I basically see elites as part of the class structure of society. For example, I have never really taken over Bourdieu's 'capital' concept, which is much used for analysing elites. In my understanding, capital is based on the commodity-form of the labour-power and its exploitation. With the exception of economic capital, I would prefer the term 'resources' instead of capital. From my critical point of view, I have problems with the idea of a field of power. Bourdieu defines this field as the space in which the various owners of capital struggle for power over the statist capital that grants power over the different species of capital, their relative currencies with respect to one another and their reproduction (above all, by the education system). I think this definition is strongly influenced by the traditional position of the state in France and overestimates the power of the state.

Bourdieu first used the term 'field of power' in his book La Noblesse d'État. In chapters that have been taken over completely from older essays in Actes de la Recherches en sciences sociales, he simply replaces the term ' dominant class'. To replace the term 'dominant class' with 'field of power' has advantages but also disadvantages. The main advantage is that the 'field' concept makes it clear that it is a battlefield whose players have to constantly fight for their positions. The main disadvantage I see is that Bourdieu, with his term the 'dominant class', made a clear distinction between the dominant faction of this class, which has mainly economic capital, and the dominated faction, which has mainly cultural capital. Many of the scientists who work with this term in elite research produce extensive correspondence analyses, in which on the one hand, the elites with a lot of economic capital, and on the other hand, those with a lot of cultural capital are listed. The fact that the former have significantly more power is usually lost. There is no clear yardstick for the valuation of the various actors in the field of power. For me, in Bourdieu's work, first of all the 'habitus' concept is decisive for the research on elites and classes because it connects structure and acting. The class specific habitus is the critical factor of the recruiting process for elite positions, especially in large corporations.

With Mills' concept of the power elite, I have problems too. Firstly, the relations between the 'power elite' and the 'ruling class' remain somewhat unclear. Secondly, Mills gives too much weight to the intentional practices of the elites. Thirdly, he tends to idealise the old middle classes as the last bastion against the victory of the power elite and overestimates the power of the military and the mass media. In fact, I have as much been inspired by historians for understanding how particular professions, social groups and classes have developed historically. The Bielefeld School, especially Hans-Ulrich Wehler himself, has been important to me. First and foremost, they analyse the historical development of classes in German society since the 
nineteenth century, especially the specific type of the German 'Bildungsbürgertum'. Like Bourdieu, they understand classes not only as a statistical category but as a historically grown reality with specific manifestations in different national contexts.

\section{After the study on top corporate managers, your research turned more quantitative?}

Yes, for two reasons. Firstly, I could no longer make interviews for the already mentioned reasons. Secondly, in spite of my studies being based on rather big samples and using much data, I was constantly criticised for being too qualitative. Often I got the commentary that this was all interesting, but what did it really prove? So, when I set out to investigate the importance of social origin in relation to educational attainment, I deliberately went entirely quantitative. I selected all people having done a doctorate in the disciplinary areas of law, economics and engineering for the years 1955, 1965, 1975 and 1985, a total number of almost 6500 persons, and I analysed their educational and professional careers. I chose these three disciplinary areas because they have historically been by far the most important ones for careers into positions of power. The analysis shows that, in spite of earning exactly the same academic title within the same years of study and with the same characteristics, like study semesters abroad for example, there were huge differences between the careers of $\mathrm{PhD}$ diploma holders depending on their social origin. In fact, there is a myth that the professional top elite in Germany, the Leistungselite, have reached their positions purely by virtue of their professional skills. ${ }^{4}$

After this study, no one complained that my work was too qualitative. In order to cope with the huge amount of data, I had to specify the classification of social origin I created for the former projects. The categories you often find in sociology, like socio-professional group, are totally unhistorical and do not take into account the history of specific professions and groups and how they have developed within a national context. If you want to understand hierarchical positions in society, you need to take historical development into account. For example, you have a lot of data from the EU. But the categories that are employed hide the leitender Angestellter in Germany, cadres supérieurs in France and senior civil servants in England; they are not the same thing. Or, take the example of Bildungsbürgertum in Germany, a fraction of the upper class and upper middle class in Germany that has no exact equivalent in France ${ }^{5}$ or England, simply because it developed in a particular historical context.

I also always consider the statistics for the period from the end of the nineteenth century until today. What demographic changes have a particular group undergone in relation to other groups? For example, in the 1950s and 1960s, senior officials in the higher administration generally came from the upper class or upper middle class,

\footnotetext{
${ }^{4}$ Der Mythos von den Leistungseliten, Frankfurt a. M.: Campus 2002. A short English version of the main results has been published 2010 in a review article called "Achievement or Origin: Social Background and Ascent to Top Management", Talent Development \& Excellence, 2 (1), 105-117. ${ }^{5}$ See for example Christophe Charle, « La bourgeoisie de robe en France au XIXe siècle » from 1997.
} 
but nowadays a significant part of them has middle class origins, something that signals a significant historical shift. When you scrutinise how social groups and class fractions change, then you can say, ok, that is the top of society. So, I attempted to give justice to the history of professions, social classes and class fractions in Germany. I created a classification system comprising 12 categories. These categories were in a sense compromises. Then, I aggregated them at a higher level to just four: upper class, upper middle class, middle classes and working classes. I differentiated the upper classes more than the rest of the population because, for me, it's most important to see which proportion of the elites originate from these classes. I could always go back to the less aggregated level. But, you should not forget history. The upper and upper middle classes, in my classification, are roughly the same as the bourgeoisie, but there are changes in the composition of the bourgeoisie. For example, until the 1960s, most members of the medical and law professions were part of the bourgeoisie. Today, this is true only for perhaps at most two-thirds of them.

This is also the time when you started making international comparisons and, in a second step, discussed the emergence of global or transnational elites?

I started carrying out international comparative studies in the second half of the 1990s, initially for the CEOs of the 100 largest companies in Germany, France and Great Britain. ${ }^{6}$ To my knowledge, this is the first international study of that kind. International comparisons have since been dominating my research. I was tired of hearing the justification for the soaring salaries of top CEOs that they were just a consequence of the global competition for these individuals. I could demonstrate that German corporations hardly gave any top positions at all to foreigners and that practically no Germans were to be found as CEO of large foreign companies.

In the research that I later summarised in my book Eliten und Macht in Europa (2007), I studied most European countries, focussing not only on economic elites, but also on administrative, political and juridical ones. I found similarities and dissimilarities. First, the more homogenous the elites are and the more socially exclusive, the stronger are general social differences in society. In this respect, there were great differences between the Scandinavian countries, on the one hand, and France, Spain and the UK, on the other. Taking the most relevant observed differences between countries into account, I also developed a typology. The first type was most clearly represented by France: very homogeneous elites, passing through the same type of exclusive elite institutions, but also changing from one sector to the other. The second type was the British: homogeneous, attendance at the same elite institutions, but no change of sector. And a third type could be found in the Scandinavian countries and, to some extent, in Germany and most other countries: no elite institutions and no change of sector.

I later expanded this research to other countries, among others the USA, Japan and China. When you study, in detail, the top business elite all over the world, you

\footnotetext{
${ }^{6}$ These studies have been published in several articles between 1997 and 2000. The most important ones are "Auf dem Weg zur transnationalen Bourgeoisie?" from 1999 and "Class-specific habitus and the social reproduction of the business elite in France and Germany" from 2000.
} 
find that it is seldom global or transnational (Hartmann 2016). Only in three countries - Australia, Great Britain and, most of all, Switzerland - may we speak of a real internationalisation of the CEOs heading the top enterprises, and for three more - the Netherlands, Canada and Germany - we may speak of a clear trend in this direction. But, in all other countries more than 90 percent of the CEOs as well as the chairmen are national. This is because so much of the recruitment to these top positions is nationally embedded. They share the same habitus, the same culture and the same language. And they do not want to live abroad permanently, even if they have the money to keep an expensive flat in London or New York. The same is true for the 1000 richest billionaires.

\section{How did you do this research?}

I use a variety of sources. First of all, I try to read the most relevant research studies I can find on elites in these various countries. This varies a lot. For example, when I prepared my book on elites and power in Europe, there was very little research to be found for Spain or Italy, whereas for the Scandinavian countries, you could find quite a lot. In the beginning of these international studies, I also relied very much on sources such as Who's Who? I nowadays get most of my information from the Internet. With patience, you can collect much precise information about individual trajectories as well as on institutions. You will find them in large databases but also in newspapers or reports about the awarding of honorary titles by universities or organisations. Moreover, you often get access to useful data on corporations or on the demographic transformations in particular countries. This is all very time-consuming, and I end up having meter-high pillars of printed information in my study room. But, it is doable.

My data do not include interviews. There are several reasons for this. As a foreigner, you need to live in a country for a long time in order to really benefit from qualitative methods. You need to speak the language and do it well, so that you understand the nuances. You have to have contacts that take time to build up. You have to understand the cultural context, which is also a historical context. You can say that these are genuine challenges for the study of global or transnational elites. I hope that other researchers can be able to cope with them, but for me it is difficult. I could, of course, do it in Germany, but as I said before, the elites all know me too well.

\section{Have you used or been inspired by network analysis approaches?}

Network analysis has played only a minor role in my research. There are two main reasons for this. Firstly, I have almost always dealt with the CEOs and the chairmen, and not with board members as a whole. Secondly, I'm a little bit sceptical towards pure network approaches. Take the example of the internationalisation of the business elite. In my last research, I have used data on the board members of the leading companies in many countries. I have found that the percentage of foreign board members is almost twice as high as that of foreign CEOs or chairmen. However, if you take a closer look at the facts, you can see the reason for this. In most cases, foreigners on the boards are non-executive. They don't live in the 
country where the company headquarter is located. They come to the headquarters only for six to twelve meetings per year. Therefore, the relatively high percentage of foreigners is not an indicator of a real internationalisation of the business elite. I think the network approach is helpful to find connections between board members connected to several companies and to several countries, but it can't say much about the key issue here, the intensity and the importance of these connections.

\section{If you look back on these 30 years, what do you consider to be the main discoveries in your research?}

There is an internal consistency in what I have done, one study leading to another, so it is difficult to point to particular discoveries. But, if I should do exactly that, I would first mention the large study of almost 6500 doctorates from four decades that showed that social origin, contrary to the opinion of Dahrendorf and others, not only operates through the education system that regulates access to elite positions. Social origin has a very direct impact on the recruitment to elites and on posteducational careers, to a large extent through habitus and everything else that comes with high social origin, such as contacts and insights. This plays a direct role in the selection of candidates for elite positions, not the least in the economic sector. The principle of social similarity ensures that top managers are vastly recruited from the upper and upper middle classes. Second, I would point to my international comparative studies that I just mentioned and that put in question the idea of an emerging transnational elite. Only in very few countries, the top management of large corporations is actually internationalised. Corporations go global, but the business elite, the top managers, who handle these corporations do not. Again, the force of social similarity governs selection mechanisms. Third, I would mention my study of the German core elite, the holders of the 1000 most important positions of power. I show that the homogeneous social origin of most members of the elite also implies very similar views on issues related to social justice, taxes and public spending. Members of the top elite who come from working class families tend to have very different views on the same issues, views that are far closer to those of the population in general.

\section{And if you think of your methodological choices?}

I have used many different kinds of methods. This has been important for me in my development as a researcher. I have conducted several hundred in-depth interviews. I have used archive studies, especially for the big study on the cohorts with $\mathrm{PhD}$ diplomas. I have systematically collected information on elites in the domains of business, politics, the judicial system and academia using many types of sources, indicators on such things as social origin, educational trajectory and even periods of residence abroad. I have sometimes tested hypotheses in my research with multivariate methods, although I then depended on collaboration with others. In the study on the core German elite, I collaborated with the Social Science Research Center in Berlin, using, for the first time, a survey carried out by experienced interviewers, professional pollsters. However, for the members of the targeted elite population who did not want to participate in the survey, I had to collect data myself about their 
origin and their educational and professional career. I needed the same type of precise information for all to get reliable results about the main characteristics of the elites.

In recent years, my research on international comparisons has, to a high extent, become more reliant on Internet resources. This allows me to go back to doing much of the data collection on my own. I use help when needed, for example, a Chinese assistant for accessing detailed information on the Chinese elite. The Internet is a powerful research tool, if used with care, since so much information is available that previously was difficult to find. There is one weakness that I should point to. Through concentrating on official positions, sometimes you may overlook people without such positions but still with much influence, especially in the business world. You may miss them if you make the selection of the top elite through formal criteria such as being a member of the board of a multinational corporation. But this is not a big issue. Most billionaires lead their companies themselves, or at least they sit at the head of the supervisory board.

The major methodological difficulty facing the elites is getting access to them. They keep their distance. They don't want to be interviewed, and if they sometimes do, they don't give their secrets away. As I said, it has become increasingly difficult for me to make interviews in Germany. However, the fact that I am well-known has also, to a little extent, been beneficial. Since the late 1990s, I am so often invited to give lectures in all kinds of contexts, large companies, associations, foundations and universities, much more often than at scientific conferences. For more than ten years, I gave approximately 70 lectures around the country per year, nowadays less. Among them are the Baden-Badener Unternehmergespräche, one of the most exclusive meetings of the German business elite. Furthermore, due to my reputation as the expert on elites for several years, I was a member of the advisory board of a foundation together with many very powerful members like CEOs of large corporations, cabinet members of the Merkel administration and presidents of the leading science organisations. So, I am often given the opportunity to discuss with people in power, so at least I know how they explain the positions of power that they hold, and I get some information about their real attitudes towards major problems, such as the financial crisis, for example.

\section{Has the reception of your work changed over time?}

Initially, my research on elites did not give much echo. However, from the mid-1990s, the interest in elites resurged, and media gave the topic more attention. My research on the careers of people with a $\mathrm{PhD}$ exam was a sort of a breakthrough for me as a well-known researcher. As for German social sciences, competition has been weak as regards elite research. I think I have benefited from my position as an outsider. When the elites became a popular topic again in the late 1990s, it was temporary. Some renowned researchers, such as the Berlin political scientist Herfried Münkler, showed interest, but then allowed the topic to fall again. I think he and others felt that the effort needed for doing systematic research in this field was very big. I also regularly came up with new empirical studies to which others had to respond. Part of this discontinuity in elite research has to do with the fact that 
sometimes researchers change sides. For example, in political science, the leader of a major elite study made in Potsdam in the mid-1990s left academia once the project was finished for a position in the Federal Association of German Banks. The research project I carried out jointly with the Social Science Research Center in Berlin on the German top elite faced a similar discontinuity. In spite of the director and three research-directors at the Center being involved in the research, the results have, to a very little extent, been published. There has been a high overturn of staff, but my interpretation is that there is also simply a lack of interest. So, for years, I am the only one who has continuously researched elites in Germany. Although the conservative media don't particularly like to leave an area that they consider to be their own to an old leftist like me, they have so far not had much choice.

\section{References}

Bourdieu, P. (1996). The State Nobility. Oxford: Polity.

Charle, C. (1997). La bourgeoisie de robe en France au XIXe siècle. Le Mouvement Social, 181(4), 53-72.

Hartmann, M. (1990). Juristen in der Wirtschaft: eine Elite im Wandel. München: Beck.

Hartmann, M. (1995). Informatiker in der Wirtschaft: Perspektiven eines Berufs. Heidelberg: Springer.

Hartmann, M. (1996). Topmanager - Die Rekrutierung einer Elite. Campus: Frankfurt a. M.

Hartmann, M. (1999). Auf dem Weg zur transnationalen Bourgeoisie? Soziale Welt, 27(1), 113-141.

Hartmann, M. (2000). Class-specific habitus and the social reproduction of the business elite in France and Germany. The Sociological Review, 48(2), 241-261.

Hartmann, M. (2002). Der Mythos von den Leistungseliten: Spitzenkarrieren und soziale Herkunft in Wirtschaft, Politik, Justiz und Wissenschaft. Campus: Frankfurt a. M.

Hartmann, M. (2010). Achievement or origin: Social background and ascent to top management. Talent Development \& Excellence, 2(1), 105-117.

Hartmann, M. (2016). Die globale Elite. Eine Legende. Frankfurt a. M: Campus.

Open Access This chapter is licensed under the terms of the Creative Commons Attribution 4.0 International License (http://creativecommons.org/licenses/by/4.0/), which permits use, sharing, adaptation, distribution and reproduction in any medium or format, as long as you give appropriate credit to the original author(s) and the source, provide a link to the Creative Commons license and indicate if changes were made.

The images or other third party material in this chapter are included in the chapter's Creative Commons license, unless indicated otherwise in a credit line to the material. If material is not included in the chapter's Creative Commons license and your intended use is not permitted by statutory regulation or exceeds the permitted use, you will need to obtain permission directly from the copyright holder.

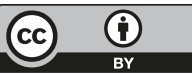

